Article

\title{
"From Scotland to the World": The Poetry of Hope Mirrlees, Helen Adam, Muriel Spark, and Veronica Forrest-Thomson
}

\author{
Dorothy McMillan \\ Honorary Research Fellow, English Literature, School of Critical Studies, University of Glasgow, \\ Glasgow G12 8QQ, UK; dorothy.mcmillan@glasgow.ac.uk
}

Received: 12 September 2019; Accepted: 5 December 2019; Published: 10 December 2019

\begin{abstract}
The four poets that provide the material for this chapter did not know each other and they probably did not know each other's work. However, they had important formative experiences in common: They were all educated in Scotland and they all left Scotland after that early education. Yet, they all retained special, although different, ties to that country, to its history, and its writing. They were all "modern" in their poetry, sometimes bizarrely so: Of each of them it could be said, "There was no one like her." This strangeness they also share, as they share a willingness, even desire, to shock, a muddling of contemporary and archaic, of real and legendary. Veronica Forrest-Thomson's "Hold on to your seat-belt Persephone" is an indicative phrase. I aim to show that these serially inimitable modern writers have complicated and intertwined Scottish and international connections.
\end{abstract}

Keywords: Scotland; ballads; kaleidoscope; Charles Bernstein; Edwin Morgan

English critics in particular, seemingly mesmerised by Irish writers, have only gingerly grappled with what has been happening north of Carlisle. We like spacemen as well as bog men. We like, and write about, both kinds of chip. We are carnivalesque, and will never give up the comedic mode. We have long feelers that extend into America and Europe rather than into England.

Edwin Morgan wrote this in The Sunday Times, 19 July 1992. He was reviewing Douglas Dunn's Faber Book of Twentieth Century Scottish Poetry (Dunn 2006). Perhaps the fact of an English publisher of an anthology of Scottish poetry provoked what seems like a warning to readers south of the border that Scots are international even if it is an internationalism that seems rather pointedly to exclude England. Morgan is glad, however, that Dunn includes Veronica Forrest-Thomson who might have been thought an English poet since her post-school life had been spent south of the border:

I was glad to see a poem by Veronica Forrest-Thomson, the Glasgow poet who died tragically in her 20s, in 1975. Her work is nothing if not avant-garde, a remarkable mixture of raw emotion, language-games, collage, and academic questioning and Dunn [... ] has chosen one of Forrest-Thomson's most accessible pieces, but might, to be fair to her, have complemented that with one of her more Wittgensteinian corkers.

Veronica Forrest-Thomson, in Morgan's version, is a Glasgow poet whose work is only fairly represented when it is recognized at once as Scottish and European, when the ballad rhythms that Morgan detected in her verse are supplemented by "Wittgensteinian corkers". This combination of Scottishness and internationalism links Mirrlees, Adam, Spark, and Forrest-Thomson. Hope Mirrlees is the first born of the four and the longest lived. She was born in Chislehurst in Kent on 8 April 
1887 and died 1 August 1978 in a nursing home in Goring-on-Thames. She had lived in South Africa, Scotland, England, Paris, Spain, through two world wars, the social and political transformations of the 1960s, and more critical and philosophical trends and modes than it is possible to enumerate; she had published poetry, novels, essays, and biographies. Her friendship with the classicist, Jane Harrison, her tutor at Newnham College, Cambridge, has intrigued her critics. Their stay in Paris provided some of the material for Mirrlees' 1919 poem, Paris, and has provoked speculation about the degree of Sapphism in the relationship of the two women. The relationship is discussed by Harrison's biographer, Mary Beard (Beard 2000, chp. 9). However, it is Mirrlees' relationship with Virginia Woolf that better reveals her connection with the other three poets.

Hope Mirrlees probably met Virginia Woolf through Karin Costelloe, a fellow student at Newnham with whom she visited Paris in 1913. Costelloe married Woolf's brother, Adrian Stephen, in 1914 and subsequently had an extraordinary and intermittently unhappy life, culminating in suicide in 1953, five years after the death of her husband. However, in 1913, she was 24 with a first-class degree in moral sciences and she and Mirrlees visited Paris, taking in, Sandeep Parmar explains, the salons of Anna de Noailles and Mary Robinson (Madame Duclaux) and meeting Edith Wharton only to be dismissively treated by her (Parmar 2011, p. xviii). Mirrlees spent much more time in Paris with Jane Harrison in 1914, 1915, and throughout 1918, and the relationship with Harrison was the central relationship of her life, but that first trip to Paris with another young woman explains some of the verve of Paris, the poem that Julia Briggs has celebrated as "modernism's lost masterpiece" (Briggs 2007). Paris was first published by the Hogarth Press, and without the Woolfs' patient reproduction of the typographical idiosyncrasies of the poem, its distinction might never have been recognized. Woolf's early estimate of Mirrlees, 17 August 1919, is caustic yet grudgingly admiring:

Last weekend, however, we had a young lady who changed her dress every night for dinner-which Leonard and I cooked; the servants being on holiday. Her stockings matched a wreath in her hair; every night they were differently coloured; powder fell about in flakes; and the scent was such we had to sit in the garden. Moreover, she knows Greek and Russian better than I do French; is Jane Harrison's favorite pupil, and has written a very obscure, indecent, and brilliant poem, which we are going to print. (Woolf 1976, p. 385)

Many years later, in 1976, J. H. Prynne was just as sensitive to the perfume worn by the young woman who had been one of his research students and who had been struck by his poetry:

Veronica would prowl round to see me, in a manner one might once have termed outré; she wore outfits of bright green or uncompromising purple, and hurled arguments about like brickbats. Her reasoning habits were very intense and she locked herself into questions like the conditions for intelligibility of poetic convention as if getting a right answer, or even a workable one, were a condition for all the details of ordinary life. She would come up against contradictions with a vivid local clarity of insight, quite without that pragmatic relativism of 'keeping things in perspective' which allows ordinary life to be merely ordinary. She wore perfume which would give the most hardened logician the staggers. She was theatrically short-sighted in ways of which she seemed entirely unaware. Her commitment to the writing of poetry was absolute and intrepid, and this commitment was in a vehemently dialectical and changing relation to her writing of poems. (Prynne 1976)

It was the overpowering scents favored by Hope Mirrlees and Veronica Forrest-Thomson that first brought them together in my mind, but other connections quickly presented themselves. Mirrlees' grandfather, James Buchanan Mirrlees (1822-1903), an engineer who designed sugar-refining machinery and diesel engines, built a mansion off Great Western Road in Glasgow. The house, Redlands, became a maternity hospital between 1902 and 1978. It has now been converted into flats. Mirrlees' father, William Julius, also an engineer and brought up partly in Glasgow, part-founded a sugar company, which after mergers, is still thriving as the Tongaat-Hulett Company. Therefore, although born 
in Chislehurst, Mirrlees was brought up between South Africa and Scotland. Hope had a Zulu nurse who taught her that language, and when she became a boarder at St Leonard's School in St Andrews, she learned Latin, Greek, and French. Hope Mirrlees' mother was a Moncrieff, rooted in the Scottish aristocracy.

Veronica Thomson had a less wealthy but equally here and there background. Her father was a rubber planter in Brunei and later Malaya. He was working in Padang Serai, Kedah, at the outbreak of WWII when he joined the volunteer Malayan forces (KDF). Veronica's brother Miles was born in Penang in 1939 and he and his mother subsequently escaped on a ship some time in 1941. The family returned to Malaya after the war and Veronica Elizabeth Marian Forrest Thomson was born in Penang on 28 November 1947. The family were fortunately on home leave when the Malayan Communist Insurgency broke out 1948 and although her father returned abroad until he finally retired from planting in 1951 or 1952, Jean Forrest Thomson remained with her children in Glasgow, which was her parents' home (Malayan Volunteers Group 2006). Mirrlees' upbringing was divided between countries and this marked her affections-and her linguistic abilities. Like Mirrlees, Forrest-Thomson was schooled in Scotland, at Jordanhill College School and, as a boarder, at St Bride's School in Helensburgh. The periods that both Mirrlees and Forrest-Thomson spent in Scotland encompassed some of their primary and most of their adolescent schooling. These are formative years and the phrase 'Scottish by formation' came to mind. The expression was used of herself by Muriel Spark in "What Images Return", an essay that she wrote in 1962 after returning to Edinburgh when her father was dying.

Edinburgh is the place that I, a constitutional exile, am essentially exiled from. I spent the first 18 years of my life, during the 'twenties and 'thirties, there. It was Edinburgh that bred within me the conditions of exiledom; and what have I been doing since then but moving from exile into exile? It has ceased to be a fate, it has become a calling. (Spark 2014)

Some of the cultural traditions of Spark's first place remain significant throughout her work. Spark remembers, for example, how the Border Ballads had captivated her from the age of 11 when she was reading them:

so repetitively and attentively that I memorized many of them without my noticing it. The steel and bite of the ballads, so remorseless and yet so lyrical, entered my literary bloodstream, never to depart. (Spark [1992] 1993, p. 98)

The notion of the ballad where so little is said and so much (and that often so dark) is implied, is a controlling force in Spark's fiction, providing the memorable title of The Ballad of Peckham Rye and title and form of the Ballad of the Fanfarlo, the poem that Spark said contained the declaration of her aesthetic. Spark's commitment to the ballad recalls another writer in exile, also Scottish by formation, who never left the ballads, although she never, after going to America in 1939, returned to the country of their origin. Helen Adam, born in Glasgow, educated mostly in Dundee, died in a nursing home in Brooklyn. Her obituary in the New York Times, 12 October 1993, described her as a "poet and composer of Scottish ballads closely associated with the Beat authors and the San Francisco school of poets."

Recordings of Adam's performances of her ballads show that, like Spark, she never lost her middle-class Scottish accent. No one recalls Hope Mirrlees as having a Scottish accent, but her mother seems to have kept hers. T. S. Eliot knew the family well and, during the blitz, regularly spent long weekends with Hope and her mother, "Mappie," at their home, Shamley Wood, nr Guilford. Writing to Eliot 30 May 1948, shortly after Mappie's death, a mutual friend, Margaret Behrens, describes her as "an extraordinary compound of fantasy, Scotchness, cleverness" (Eliot 2017, p. 637, note 1). Gareth Farmer, in his recent critical assessment of Veronica Forrest-Thomson, speaks of her light Glaswegian vowels at her 27 April 1967 Essex Arts Festival reading (Farmer 2017, p. 25).

All four were privately educated in girls' schools in Scotland: Mirrlees at St Leonard's in St Andrews, Helen Adam in Seymour Lodge, Dundee, Muriel Spark in James Gillespie's, Edinburgh, and Veronica Forrest-Thomson in St Bride's in Helensburgh, all schools that offered more intellectual 
opportunities and less social variety than co-educational state schools. The privilege of a good education has to be balanced against the desire that such schools might provoke to escape the limitations and constrictions of privilege and protection.

The four poets are linked by literary as well as biographical connections. Mirrlees in Paris draws on the Baudlairean flâneur tradition; Spark takes her characters in her short story "The Seraph of the Zambesi" and her long poem The Ballad of the Fanfarlo from Baudelaire's short story La Fanfarlo (Baudelaire 1847); both Mirrlees and Forrest-Thomson in different ways draw on French modernism, particularly on Apollinaire; through Robert Duncan and Charles Bernstein Helen Adam is connected to $\mathrm{L}=\mathrm{A}=\mathrm{N}=\mathrm{G}=\mathrm{U}=\mathrm{A}=\mathrm{G}=\mathrm{E}$ poetry and thus to Veronica Forrest-Thomson. There is always something in one of the poets that sends me to another. But there is, I would suggest, a more radical connection. My contention is that these four poets, born between 1887 and 1947, dying between 1975 and 2006, share a Scottish formation, which, no matter what their later experience may have been, ensured that for all of them, as for Muriel Spark, Scotland remained the country that they were exiled from. The result is, in each case, poetry that might be called kaleidoscopic in that it admits disparate, even clashing elements and allows pattern to be formed from these without imposing a single view. Mirrlees, in an essay "Listening in to the Past", which she originally published in The Nation and Athenaeum, 11 September 1926, invokes the kaleidoscope "the prettiest toy ever invented, and the most entertaining of all the thieves of time". She concludes her essay by remembering:

a particularly glorious kind of kaleidoscope for which you yourself provide the materials for the patterns. Under the lens there is a little tray, and on this you place any thin brightly coloured scraps you can lay hands on ... the silver paper off chocolates, for instance, the petals of flowers, and so on. And, as you gradually add to this collection of scraps, you sometimes find-from the addition, say of a purplish-brown element given by a wallflower's petal or from the brilliant blue of a butterfly's wing, rifled from your childhood's collection that both the colours and design of the patterns become much more beautiful. (Mirrlees 2011, pp. 88-89)

Since the essay is concerned with the recovery of the past, she also invokes the notion of an aural kaleidoscope and tries to listen to the mixture of horror and cruelty and domesticity that is to be found in the witch trials in Pitcairn's "Criminal Trials of Scotland". The trial that fascinates most is that of the "royal witch" Mary Stuart of whom Pitcairn writes that she exercised "some enchantment, whereby men are bewitched". We owe the bewitchment of the kaleidoscope itself to the Scot Sir David Brewster who invented it in 1816.

In spite of her fascination with Scottish history, Hope Mirrlees might seem the least convincingly Scottish by formation, not because she did not spend formative time in Scotland but because so much about her life was unsettled from an early stage: England, South Africa, Scotland, and by the time she was 16, England again. St Leonard's School was and is the most anglified of the girls' schools attended by the four. It has tended to prepare its students for English Examinations and to send them, when they do go to University, to Oxford or Cambridge. Mirrlees went to RADA and then Newnham, Cambridge, where she was taught by Jane Harrison, the shaper of much of Mirrlees' later life.

Yet Mirrlees' years at St Leonard's left their mark on her. After mostly home schooling she entered St Katharine's, the junior school of St Leonards, in 1899, moving on to the senior school St Leonards itself in September 1901 and leaving in April 1903. She was in the boarding house, Bishopshall West, the Housemistress of which was Miss Abernethy, who latterly kept as pets two terriers and a parrot ${ }^{1}$. The Headmistress from 1896 was Miss Julia May Grant. She was the daughter of Sir Alexander Grant, Principal of Edinburgh University, classicist, editor of Aristotle's Ethics. Grant's wife, Susan Ferrier, was second daughter of James Frederick Ferrier, the distinguished and controversial philosopher,

1 I am grateful for this information from the Librarian of St Leonard's, Angela Tawse, 17 January 2019. 
nephew of Susan Ferrier, the novelist. Therefore, the school was guided by a woman with a distinctive academic heritage, firmly Scottish and firmly intellectual.

Hope Mirrlees left no exceptional record at school, yet four years of an impressionable period of her life under devoted teachers committed to the study of classical and modern languages did much to prepare the ground for her attachment to Jane Harrison. After Cambridge and a broken engagement, Mirrlees lived off and on in Paris, spending almost all of 1918 there, studying Russian at the École des langues orientales and reading "avant-garde poetry, including that of Apollinaire, Pierre Reverdy's journal Nord-sud, and Jean Cocteau's sequence Le Cap de Bonne-Espérance, which she claimed 'liberated' her into writing her own experimental poem" (Julia Briggs, ODNB). Apollinaire's Calligrammes, 1918, exerted some pressure on Mirrlees' Paris (Mirrlees [1919] 1920). The poem is dated Spring 1919, although it was not published until 1920. Paris begins "I want a holophrase", a phrase, that is, that will express and unify everything, but the poem is, like Apollinaire's calligrams, pictorial and aural as much as it is linguistic. It invites us to look, to listen, and try to bring together. For the first 300 odd lines, the poem follows a female protagonist (she is asked "Vous descendez Madame" by the underground attendant) on a journey in the Paris Métro under the Seine, to Concorde, then through the Tuileries Gardens, past the Louvre, along the Rue Saint-Honoré. She retraces in her mind and as a physical flâneur, the Louvre, the Ritz, the Palais-Royale, the Hôtel de Ville. Readers are dependent on the observations of this woman but are not bound by them, since what she sees in Paris is fixed but what it makes her think about is not, and it may not be quite what the reader thinks about. Therefore, the poem pulls in its readers while still allowing freedom for memory and imagination.

About three-quarters through the poem, the linear perspective shifts to a panoramic view from an "old Hôtel" in the Rue de Beaune, which was Mirrlees' address ${ }^{2}$. The walker has come home and that point of rest allows at last a kaleidoscopic view. The disparate elements of the poem can be brought together in a gaze, but more than one gaze is possible and so the poem can be repeatedly refocussed and reviewed. Mirrlees' description of the kaleidoscope in "Listening to the Past" explains how Paris can be made to work. The poem makes available a tray upon which the poet can place a collection of people and things that represent Paris in the past and the present and in the imagination. A single gaze will bring these things together in a meaningful way, but a turn of the platform will provide a different, but equally extraordinary pattern. This is enabled by the refusal of a conventional poetic structure and is made possible by the kind of visual fragmentation that Mirrlees effects. Mirrlees' Paris is a kind of poetic roundabout as she seems to warn us at the beginning with her picture of little boys on wooden horses ${ }^{3}$.

What makes the poem courageously modern are the pieces that Mirrlees places on her viewing platform. Hope Mirrlees was 32 when Paris was finished; her life had been thus far protected by money and confined by a polite girls' school and a female university college. Paris allows the muck, the filth, as well as the beauty to produce visions that encompass the misery and waste of war in the present and the past. Paris, as all commentators on the poem note, was the site of the Peace Conference, which culminated in the Treaty of Versailles, signed on 28 June 1919. The Treaty was disapproved of by a number of observers, including the economist Maynard Keynes, friend of Virgina Woolf, who walked out of the Conference in protest at the treatment of Germany, although Mirrlees may well have reached the poem's unsympathetic view of President Woodrow Wilson on her own:

2 Hotel de l'Elysée, 3 Rue de Beaune. The Rue de Beaune is on the Left Bank, but close to the river and thus is well placed for a view of both banks of the Seine and of the Île de la Cité.

3 The little boys on their horses may also be intended to invoke Mark Gertler's Merry-go-round, 1916. 
President Wilson grins like a dog and runs about the city, sniffing with innocent enjoyment the diluvial urine of Gargantua. ${ }^{4}$

Wilson typifies the failures that the poem tries to combat. Paris's present cannot be comprehended without awareness not only of its own past but of all the pasts that have gone to make that past. That awareness is achieved by acknowledging what is both squalid and glorious in the modern city by dredging below the surface, while also looking to the sky:

But behind the ramparts of the Louvre

Freud has dredged the river and, grinning horribly, waves his garbage in a glare of electricity.

...

Soon les Halles will open,

The sky is saffron behind the two towers of Nôtre-

Dame.

The poem begins in the morning and ends with a new dawn. Its last words are 'JE VOUS SALUE PARIS PLEIN DE GRACE'. It then concludes with the astronomical symbol for the Great Bear, which had become the chosen symbol of the relationship between Mirrlees and Harrison and so the conclusion is both public and private, personal and political (Parmar 2011, pp. 3-17).

The plenitude of Paris is inexhaustible- the dawn at the end of the poem is a beginning and the next Parisian day could be as full as the one before and all the elements on the kaleidoscope tray could be different, yet just as meaningful. However, Paris is (like The Waste Land) a rather de haut en bas poem-it is written for a reader unusually well-educated or at least well-supplied with notes. The reader must have had or must seek to acquire the advantages of privilege. In Mirrlees' case, that privilege was, in part, a consequence of her father's money and her mother's ancestry. In her later work, Mirrlees explicitly investigated that ancestry, her own formation. The Scottish parts are explored in The Counterplot, (Mirrlees 1924), Mirrlees' third and last novel. The novel is advertised as "a study of the literary temperament". Its central figure, Theresa Lane, tries to understand her place within her own family and in the wider world and decides that the best way to do this is through art itself. She writes a play, which is performed within the novel. The play, The Key, purports to explain Theresa's place and to offer a way of expressing her deepest needs and desires. It is in the mode of a Spanish Auto Sacramental, set within a medieval convent. The author figure plays Sister Pilar who reveals that her virtuous appearance is just that, an appearance; in truth, she is "Christ's adulteress" (The Counterplot, p. 312). Theresa's family are mystified by her play and so were contemporary critics: Sandeep Parmar quotes an anonymous contemporary reviewer of Mirrlees' last novel, the fairy story, Lud-in-the-Mist (Mirrlees 1926), whose praise of that work is tempered by condemnation of the "all-embracing pedantry" of The Counterplot (Parmar 2011, p. xxiv). Yet, the detail is intriguing. Theresa, in the course of the novel, falls in love with Munroe, an associate of her father. He is from Inverness-shire where "they've got a special accent ... not Scotch, but a sort of genteel English" (p. 44). Munroe, in the end, does not choose Theresa but becomes a Roman Catholic priest, a life towards which he has been moving:

"Hush, you wee thing, hush! You're havering, you know, just havering. You-Sister Pilar-you're not going to try and wreck a vocation." (p. 321)

4 When Rabelais' giant Gargantua first goes to Paris, the ignorant crowds of people so annoy him that he urinates over them, drowning thousands. The survivors laugh, saying that they have been washed as a joke, "par ris", and the city is renamed Paris (Gargantua, c. 1534, chp. xvii). 
There is no marriage of the would-be artist and the soft-spoken Scotsman. It is not clear how much this is to be regretted, but like her character Munroe, Mirrlees herself converted to Catholicism in 1929 after Jane Harrison's death. It is of interest that Mirrlees should focus on the "literary temperament" and that it proved impossible to ignore the Scottish pressures on that temperament. The Counterplot has never established itself in any canon, modernist or feminist. It is remarkably difficult to get hold of a copy even to read. It had an odd devotee in Christopher Isherwood in his diary on 24 March 1955:

Am reading-after about thirty years-Hope Mirrlees's novel The Counterplot, which I got here, after long advertisement. I find I know whole passages of it nearly by heart. It must have been one of the truly "formative" books in my life. And yet it represents so much that I used to imagine I hated and was fighting to the death-Cambridge cleverness and the whole Waste Land technique of describing moods by quotations from the classics-in fact, indulging in moods that were nothing else but the quotations themselves. It's a second-rate book, but I still feel some of the charm it used to have for me. And just because its "sophistication" is transparently naïve, I find it warmer and more sympathetic than that of the early Aldous Huxley. (Isherwood 1997, vol. I, p. 483)

Isherwood's comparison to The Waste Land recognizes The Counterplot as a modernist text despite its mannered prose. Here, too, is Guy Cust, a friend of Theresa's brother Arnold, who after the war gives up his intention to be an academic and instead settles in London where he tries to express in poetry what he calls:

"the modern mysticism" - that sense, made possible by wireless and cables, of all the different doings of the world happening simultaneously: London, music-halls, Broad Street, Proust writing, people picking oranges in California, mysterious processes of growth or decay taking place in the million trees of the myriad forests of the world, a Javanese wife creeping in and stabbing her Dutch rival. One gets the sense a little when at the end of The Garden of Cyrus Sir Thomas Browne says: "The huntsmen are up in America and they are already past their first sleep in Persia." Its finest expression, he said, was to be found in the Daily Mirror. (p. 32)

Cust's poetic quest seems fulfilled in the fragmented plenitude of Paris.

Sandeep Parmar includes in her excellent edition of Mirrlees' poems, "My Mother's Pedigree" the first section of "what appears to be draft in progress" from Mirrlees' notebooks. Her interest in her ancestry is confirmed by her compiling "a history of her maternal ancestors, the Moncrieff family in the 1950s" (Parmar 2011, p. 134). The poem represents her mother's pedigree as including blood and beauty, the violent struggles for power that oppresses women from "the little princess Matilda" to Mary Stuart, whose murdered "lover", Rizzio, rubs shoulders in the poem with "Earl Beardie" who played cards with the devil and the "fierce Ogilvies", the family that fought on both sides in the wars of independence. The poem looks at the muddles of the past and concludes:

And yet all of it by the tectonics of

A thousand genes builds-me who am at

Least articulate. (p. 64)

That notion of tectonic plates that construct the poet also harks back to the structures of Paris-a carefully built poem, kaleidoscopic in its formation of pattern out of disparate elements, but which is also describable as formed out of layers of tectonic plates of past and present.

In Angry Rain, a memoir of his days among the poets, Maurice Kenny writes: "Helen Adam's tiny apartment on East Eighty-Second Street, which she shared with her sister Patricia, had ... a huge and diverse collection [of books] assembled in such unusual places ... in the oven, as legs for the dining table, and so on" (Kenny 2018, pp. 134-35). That sense of much variety compressed into a small space, in the center of a great world, also typifies the dark supernatural ballads that form Adam's poetic 
corpus. It is a corpus that she began building very early, composing poetry apparently from the age of two and being published by adoring elders before she was 14. Adam and her younger sister Pat attended Seymour Lodge Girls School in Dundee. The school, which moved its site during the war from Dundee to Crieff, no longer exists, but it is possible to get some sense of it from bits and pieces in the local newspapers of the time. The sympathetic biography of Helen Douglas Adam on the Scottish Poetry Library website (Scottish Poetry Library Website) remarks that in later life Helen Adam rejected these early works, that she was embarrassed by the childlike charm of The Elfin Pedlar and Tales Told by the Pixie Poole (Adam 1923). Yet they are connected to her later "supernatural ballads which tell of fatal romances, darkly sadistic sexual affairs, jealous lovers, and vengeful demons" ("Helen Adam's Sweet Company", Prevallet). If you love the mysteriousness of the occult yet wish to obliterate your sugary childhood encounters with it, then you might well turn to the dark side.

I imagine Helen Adam was glad to get away from her early Scottish places. She attended Edinburgh University, after which she and Pat moved to London and made some kind of living from journalism but when, after their father's death, they went with their mother to a family wedding in the United States and were trapped there by the war, there is no evidence to suggest that the trap was for them other than a release. The women settled initially in New York and in 1949, moved to San Francisco where Helen Adam became involved with the Beat poets and their circle, particularly with Robert Duncan and his partner the artist/collagist Jess Collins, known always as Jess. Helen, assisted by her sister, Pat, published a good deal, although they were always struggling to make ends meet. Another Scottish exile, Muriel Spark, found in her experience as a girl of slender means the material on which she founded her literary fortunes. Adam, although remarkable, did not have Spark's genius, nor her ruthlessness. Indeed, it is in part Adam's vulnerability, the trailing odor of Scottish middle-class respectability, that simultaneously hinders Adam's advance, and characterizes her specialness.

Prepare to be astonished. How on earth, you wonder, can a Scot, woman poet and collagist possessed of an overcomingly remarkable imagination, combined with an intense involvement in Scottish history, Dante, the Victorian Romance novel and art, and in really weird animals in various beings and doings, fit so perfectly, no matter how oddly, into the San Francisco Renaissance? Prepare to meet Helen Adam. (Caws 2018)

There is an evident connection between Adam's collagism in Ghosts and Grinning Shadows (Adam 1979) and the kaleidoscopic method of Mirrlees. Adam, like Mirrlees, mixes dirt and darkness with mysterious light. Mirrlees' last novel, her fairy fantasy, Lud-in-the-Mist, exploits the mixture of horror and gentility that characterizes some of Adam's work, but Mirrlees did not also use her physical self and appearance, did not perform in Adam's manner. Adam was not unaware of her oddness; she may indeed have felt that her best advertisement was the uncomfortable combination of the dark horrors of her verses and the afternoon-tea appearance of their creator, reader, and chanter.

Helen Adam's talk with the Beat poet, Anne Waldman, is available on YouTube. Adam is wearing a flowery dress and a turban with beaded decoration at the front. She speaks with friendly and captivating charm:

Almost all my ballads have destructive women in them. I really don't know particularly why. I guess something in my remote childhood must have made me feel that women were something uh savage and strange and completely without remorse. But, of course, I was more or less brought up on Scotch ballads and there's no such thing in the Scottish ballads as forgiveness of sins-it's all an eye for an eye and a tooth for a tooth, you know. They're all absolutely ruthless and the fairies in them are powerful creatures, not pretty little, dainty little English fairies at all. (https://www.youtube.com/watch?v=EwYjODoZG7I)

Had Adam read Hope Mirrlees' Lud-in-the-Mist, she might have come to see English fairies as only deceptively pretty, but that is another story. Adam's dark poems tend to be repetitive. Partly this is a question of ballad technique, but it is also her inflexible design on the listeners' nerves. She is at 
her most dynamically original when she uproots the Scottish ballads and locates them firmly in her adopted country. Thus, the "Cheerless Junkie's Song" works better than the more Scottish ballads in the Selected Poems and Ballads, the volume that has had most circulation outside the United States. The internet has, however, made Helen Adam available to all and Adam can be heard celebrating the Cheerless Junkie on YouTube. Her triumphant punning conclusion "Brother he died high" works partly as the defiance of an ageing Scottish lady who refuses to be subdued by polite protocols. The best site for Helen Adam material is PennSound, the University of Pennsylvania's website for contemporary writing. It offers the whole performance of San Francisco's Burning (Adam 1977), a lyric play that Adam wrote with her sister Pat. The online version is performed by the Audio-Experimental Theatre on WBAI, 17 July 1977, produced by Charles Ruas. In this version, Helen Adam herself reads Miss Mackie Rhodus and Anubis. It is perhaps enough to simply give this information to demonstrate that Adam's work catches its listeners between hysterical laughter and terror. X. J. Kennedy comments on Adam's Selected Poems that her ballads and songs "will stay green when most poetry now in fashion is nothing but dried-up leaves" (Adam 1974, blurb).

It is now almost a cliché to point out that Muriel Spark, world famous as a novelist, always thought of herself as a poet. The inscription on her tombstone reads 'MURIEL SPARK/POETA/1918-2006. Like Helen Adam, Muriel Spark was a poetic prodigy. James Gillespie's School gave Spark the opportunity to shine as a poetess as well as giving her Miss Jean Brodie in the person of Miss Christina Kay, the teacher who took her to hear John Masefield reading, giving Spark a poet who continued to be a poetic hero for her, if not strictly a modern one. Throughout Spark's famously uncomfortable time with the Poetry Society, as feisty editor of The Poetry Review, 1947-1948, where in spite of the antagonistic attitude of a number of the Society's stalwarts, which resulted in Spark's dismissal ${ }^{5}$, she wrote sharp editorials, beginning with "Cannot we cease railing against the moderns?", and managed to introduce payment for the contributors, she continued to think of herself as a poet trying to make enough money to support her vocation. In 1951, she wrote a poem, which uses the traditional form of the ballad to construct a startlingly modern and startlingly difficult personal manifesto. Spark told her then lover, Howard Sergeant, that "The Ballad of the Fanfarlo" was her "central statement in verse so far" (Stannard 2004, p. 91). Even to think of a poem in these terms is to conceive of oneself as seriously committed to the vocation of the poet. The poem features a cast of characters drawn not from Baudelaire's poetry, but from his short story, "La Fanfarlo", from which the poem's epigraph and some of its details are also taken. Samuel Cramer, the child of a pale German and a brown Chilean woman, seeks his ideal self, Manuela de Verde, has encounters with the dancing girl, la Fanfarlo, with a steel chair, which calls him No Man, with a red light, other objects, and with the courteous figure of Death. The compelling effects do not quite compensate for the reader's bewilderment.

The Ballad is a paradox. It is faithful to the simplicity of utterance that characterizes the ballad; but it is also confusingly obscure. Traditional ballads are not without difficulty for the listener, but their difficulty is usually a consequence of mystery, of not quite knowing the details of the story. In Spark's poem, it is not simply a question of not knowing the whole story as of not knowing whether there is a whole story to know. It comes as a relief when Cramer is addressed by Death, for Death is a much more familiar and comfortable character than a steel chair. The reader's puzzlement is a consequence of Spark writing for herself, producing a manifesto that will underpin her subsequent work, rather than an artefact that has its own existence.

If we situate the Ballad beside the visual art of the time, of the Dadaists and the Surrealists, we might be more attuned to encounters between the human and inhuman objects, to the transformation of the human into the inhuman and vice versa, yet somehow Spark's sense of humor abandons her in The Ballad of the Fanfarlo. It comes back when Samuel Cramer and the Fanfarlo turn up again in "The Seraph of the Zambesi", which won the Observer short story competition and confirmed that

5 Spark insisted upon being dismissed so that she was financially compensated. 
Spark's talent was better adapted to fiction than poetry. Nevertheless, she remained a poet and a challenging one to the end and the publication of All the Poems (Spark 2004), edited by Barbara Epler in 2004 and reissued by Michael Schmidt as Complete Poems in 2015, confirm the claim that she made for herself: "Although most of my life has been devoted to fiction, I have always thought of myself as a poet. I do not write 'poetic' prose, but feel that my outlook on life and my perceptions of events are those of a poet" ("Foreword to 2004 edition" in Spark 2015, p. xiii). Schmidt is probably right to maintain Epler's non-chronological arrangement of the poems, since they do not seem to show any development through time. The earliest poem in the collection is "The Fall", which Spark dates 1943, when she was 25 and still in Africa. The poem speaks of extinct or nearly extinct beasts and asks how these seemingly innocent creatures have sinned to fail "the finals in history" (p. 34). "Report on an Interrogation" (p. 86) is dated 2006 and is still preoccupied with notions of guilt and innocence and the impossibility of determining the difference between them. By then Spark was 84, yet the first poem is as "modern" as the second and the questions it asks as unanswerable, and unanswered in spite of Spark's long literary life and her celebrated conversion to Catholicism. There is an appropriateness in placing "Report on an Interrogation", with its insecurities about being sure of anything in the human sphere, immediately after "Sisera" (p. 85) written 53 years earlier where the poet takes issue against the triumphalism of Deborah, who is so sure that God is on her side: "I am for Sisera". In "Report on an Interrogation", Spark retains her ability to leave her readers with the uncomfortable feeling that most of their daily assumptions are just that-assumptions, unproven.

On the face of it, Helen Adam and Veronica Forrest-Thomson seem more than continents apart. The $\mathrm{L}=\mathrm{A}=\mathrm{N}=\mathrm{G}=\mathrm{U}=\mathrm{A}=\mathrm{G}=\mathrm{E}$ poet, Charles Bernstein, offers a link between them. It is a tribute to Bernstein's flexibility that he is able to applaud both Adam's apparently archaic methods and the sophisticated critical aesthetic of Forrest-Thomson. He generously praises Kristin Prevallet's A Helen Adam Reader: "Adam is the most exuberantly anachronistic of second wave modernist poets. Her magical, macabre, magnificently chilling ballads open a secret door into the Dark with rimes both gruesome and sublime" (Prevallet 2007. Advance praise). Bernstein's approval of Forrest-Thomson is more predictable, given her 1971 collection, Language-Games, but he was early in his admiration of both her poetry and the critical work, Poetic Artifice, 1978, which although published after Forrest-Thomson's death, implicitly offers a defense of her own poetic aims. Bernstein's "Artifice of Absorption: An Essay" spends a good deal of its argument in debate, agreement, and modification of Forrest-Thomson's positions in Poetic Artifice: "Veronica Forrest-Thomson ... notes that artifice in a poem is primarily marked by the quality of the poem's language that makes it both continuous and discontinuous with the world of experience". Both Bernstein and Forrest-Thomson insist that "content never equals meaning" and deprecate attempts to reject or explain away "difficulty" in poetry (Bernstein 1987).

The Scottish poet, Edwin Morgan, provides another link between the two. Edwin Morgan was the first to bring Helen Adam back across the Atlantic and he finds that her achievement is enabled at once by her Scottishness and by her distance from Scotland:

Helen Adam is possibly unique in the sense that she would never have made anything of her poetry, even though she wrote a lot of it, if she remained in her native place. She was a latent poet who needed the jolt of an entirely different environment to bring to the surface what was subterrraneanly there. Later in life she took out American citizenship, and in American bibliographies she is called an American poet. But that won't do. She was unmistakably a Scottish poet who learned a new boldness and vivacity in California, but who never lost touch with the Scottish oral tradition she grew up with.... we can say that she moved from Scotland to the world, and made something of it. (Morgan 1999)

It was Edwin Morgan, too, who was the first to recognize Veronica Forrest-Thomson as a Scottish poet. Like Adam and Spark, Veronica Forrest-Thomson tried her hand at poetry from an early age. As Veronica Thomson, she published a few poems in her school magazine, The Bridesian, between the ages of 11 and 14, and "Miserere Nobis", a little hopeful prose piece about love between a Protestant 
boy and a Roman Catholic girl during the religious persecutions of 1587, the year Mary Stuart was executed (Thomson, Veronica 1960-1961, pp. 49-52) . However, it was a harder-edged girl who wrote to Edwin Morgan in February 1965 when she was 17 and preparing to go to Liverpool University. She tells Morgan that she has heard his Third Program talk on Concrete Poetry. She says she believes it to be the first healthy development in poetry since the war:

Though didn't Apollinaire try something similar? It was a pleasant surprise to hear some intelligent poetry which showed responsibility towards the exploration of language instead of the usual egotistical watered down angst-dichten which seems to monopolise the Third Programme poetry readings. (MS Morgan DT/7. 16/2/65) ${ }^{7}$

It is wonderful to hear this intellectually confident young voice of Veronica Forrest, the name she adopted before Forrest-Thomson as her writing name. It may seem illogical to want to know more about Veronica Forrest-Thomson's life when she dismissed the practice, typified for her by the treatment of Sylvia Plath, of reading biography out of or into poetry, as the bad Naturalisation of the artifice of poetry (Forrest-Thomson 2016, p. 225).

Jonathan Culler, her husband from 1971-1974, explains the objections to biographical criticism:

The work is a product not of a biographically defined individual about whom information could be accumulated, but of writing itself. To write a poem the author had to take on the character of poet, and it is that semiotic function of poet or writer rather than the biographical function of author which is relevant to discussion of the text. (Culler 1981, p. 38)

However, the desire of the writer to take on the "character of poet" is itself an emotion experienced by the biographical subject. Even those whose interest is focused on intertextuality, or the Artifice of the individual poem, may well wish to know something about the life of the writer. Forrest-Thomson has been insufficiently located in her places and times by her critics. No one seems to be interested in where she grew up, in where she went to school. The most recent work on Forrest-Thomson by Gareth Farmer does not mention Edwin Morgan. Forrest-Thomson's recent admirers have all very much been that-admirers. It may be that their admiration makes them tentative about asking questions about her life. Nevertheless, to adopt one of Muriel Spark's favorite qualifiers, although it is language, Poetic Artifice, that makes good poetry, we might still be allowed to feel that it is the poet that finds the language and that it is life experience that at least in part creates the poet. Veronica Thomson's life experience certainly included Scotland.

Between February 1965 and May 1973, Forrest-Thomson kept in touch with Edwin Morgan by letter and they met in Glasgow on a number of occasions. Until February 1970, she signed off as Veronica Forrest, then as Veronica Forrest-Thomson, then Veronica. Only one of her letters, in August 1971, uses the salutation Edwin and she reverts to Mr. Morgan in her last letter, but presumably because she was asking for his help with the publication of her collection On the Periphery. In his attentive and informative replies, Edwin Morgan addresses her at first as Miss Forrest, then by 1968, as Veronica. They discussed her own work, which Morgan read. They discussed, or at least mentioned in passing, Concrete Poetry and Ian Hamilton-Finlay, Cavan McCarthy, Glynn Purslove, various little magazines, Fenellosa, Empson, Richards, Hugh MacDairmid, Wittgenstein, J. H Prynne, Philip Hobsbaum, Gabriel Harvey, Spenser, Barthes, TelQuel, Graham Hough, L. C. Knights, Morris Cox, Ashberry, Dadism, Surrealism, Structuralism. They discussed the possibility of Forrest-Thomson doing graduate research in Glasgow, her decision to work on literature and science in Cambridge after she got a first at Liverpool.

6 I am grateful to Alister Minnis, Depute Head of Lomond School which incorporates the old St Bride's, for information about the school and access to The Bridesian.

7 I am grateful to Jonathan Culler for his kind permission to quote this passage and the poem "What are we". I thank the Estate of Edwin Morgan for allowing me to read Veronica Forrest-Thomson letters. 
The joys and lively irritations of the early letters give way to the depression of struggles for work and publication, but even that depression is presented without self-pity: "I've just finished a book on poetic theory too which I can't find a publisher for; everything is cracking up" is immediately followed by "However I should be glad of any advice you could give me" (MS Morgan DT/7) ${ }^{8}$. Forrest-Thomson may have been on the periphery, but she never presents herself as being on the edge.

Edwin Morgan was deeply affected by Forrest-Thomson's premature death. He wrote a sequence of 10 Unfinished Poems for her, published in The New Divan, 1977. His later appraisal of Forrest-Thomson is both personal and professional:

She was probably better known in England than in Scotland, but she can be seen as belonging-in her own strange and oblique way-to the revival of poetry that has gone on in Glasgow during the last decade or so. She was a spiky, difficult character of great intelligence and wit, engaging, vulnerable and lonely. I liked and admired her very much. She wrote both poetry and criticism, and the influences on her work were variable and formidable: the French structuralists, Wittgenstein, John Ashbery, J. H. Prynne ... but shot through with a raw, moving, almost ballad strain from time to time, and especially in her love poetry. (Morgan 1990, p. 373)

Morgan's poems for her are an impressive homage, not least in their title Unfinished Poems, a title that refers to the artifice rather than the status of the poems. Their last lines all refuse the completion of a full stop, as though Morgan were refusing the event that had so cruelly brought Forrest-Thomson's life to a stop. The poems cannot reach a formal close because Forrest-Thomson, by reaching her end prematurely, has left herself and her work tragically unfinished. It is all the more important, therefore, not to neglect any of the elements that made Veronica Forrest-Thomson the writer that she was to the last becoming. The "almost ballad-like strain" of Forrest-Thomson's poetry may seem less evident than in Adam or Spark but, and this is possibly what Morgan discerns, nursery rhymes, children's game verses, incantations from fairy story and legend hover in and above the poems from early to late. In "Through the Looking-glass", 1967:

Mirror, mirror on the wall

show me in succession all

my faces

$\cdots$

But if, in some unlucky glance,

I should glimpse naked circumstance

in all its nowhere-going-to

may you crack before I do. (Forrest-Thomson 2008, p. 29)

What concerns Forrest-Thomson here is that we have used the language of these familiar verses since childhood without ever enquiring about the words. The words themselves have enchanted us, until the poet makes us think about them as well as use them. That 'crack' invokes a fragile life as well as the physicality of the mirror; and that fragile life is still being invoked at its end, albeit an end that should have been a beginning. In I have a little nut-tree, c.1974, the language of childhood is trying to cope with the miseries of maturity:

I have a little nut-tree

Nothing will it bear

But a silver anguish

And a golden tear. (Forrest-Thomson 2008, p. 148)

8 MS Morgan. DT/7. University of Glasgow Library, Special Collections. Morgan's letters have been published (Morgan 2015). Forrest-Thomson's remain in manuscript. 
My list of topics from the letters of Forrest-Thomson and Edwin Morgan is not exhaustive but it is already kaleidoscopic and Forrest-Thomson herself introduces the notion of the kaleidoscope in "Provence" from her earliest published collection Identi-kit, 1967:

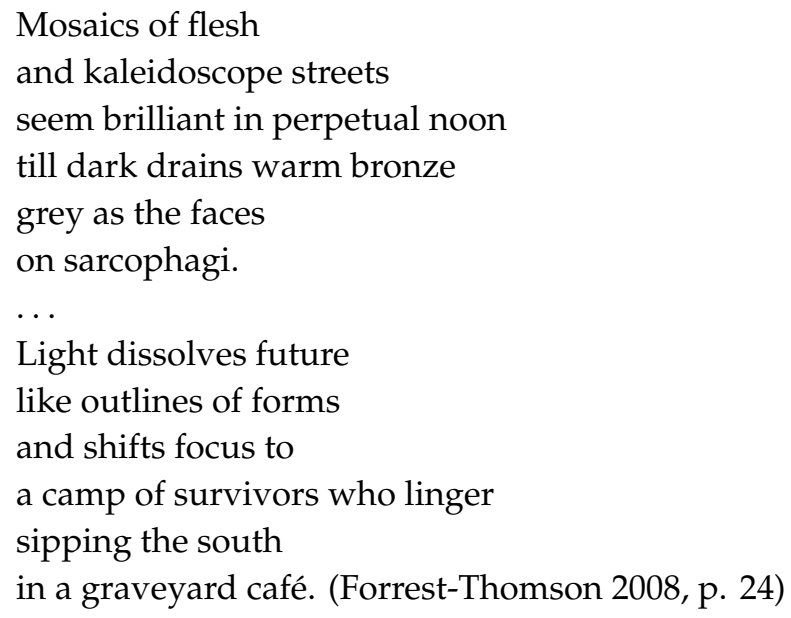

This four-verse poem shares some of the methods of Mirrlees' Paris without the visual complications of that poem. The poem may be read according to the placement of the reader in the present or the past, in light or shade, looking at the beautiful or the disintegrating, or encompassing all of these things and times at once. Even some of the radically subject-matter-refusing poems of Language-Games connect oddly with Paris. "Antiquities" is focused at first on the city of Paris and initially proceeds in a similar way to Mirrlees' poem, depending as it does on the vision of one pair of eyes bringing the poem's pieces together. This singular mode of perception makes the work of these writers teeter on the autobiographical and confessional in spite of Forrest-Thomson's warning note that the underlying theme of the poems in the collection is: "the impossibility of expressing some non-linguistic reality, or even of experiencing such a reality". "Antiquities" is a poem that could not have been written by someone who had not been to Paris-biographical fact is a necessary precondition of the poem.

Her later poetry is increasingly packed with quotation and allusion and pun, which betrays the personal even as it seems to be concealing it. "Address to the Reader from Pevensey Sluice" pulls in a real warning board at the sluice:

\section{DANGER SUBMERGED STRUCTURES}

and all at once Transformational Grammar

"peoples" the "emotional landscape"

with refutation. (Forrest-Thomson 2008, p. 116)

The board has that effect especially if you have just become divorced from a specialist in structuralist poetics ${ }^{9}$. Forrest-Thomson's allusiveness has some of the characteristics that Isherwood stigmatized as Cambridge and Modernist cliché in Mirrlees' The Counterplot. However, Forrest-Thomson is so daring in her use of quotation to signal emotional states that her readers are willingly ravaged: "So here we go for another trip and hold on to your seat-belt, Persephone" "The Garden of Proserpine", in Forrest-Thomson 2008, p. 139). "Cordelia: or 'a poem should not mean but be'" is so packed with allusion and quotation that it would take as many notes as Paris requires to exhaust its possibilities and then the kaleidoscope platform might turn to produce a different view of the same elements.

Spring surprised us, running through the market square 
And we stopped in Prynne's room in a shower of pain

And went on in sunlight into the University Library

And ate yogurt and talked for an hour.

You, You, grab the reins.

Drink as much as you can and love as much as you can

And work as much as you can

For you can't do anything when you are dead. (Forrest-Thomson 2008, p. 157)

"Lemon and Rosemary", the last poem in Collected Poems, refuses the kaleidoscope, refuses to make patterns out of the mess of a disorganized life: "Though my deserted frying pans lie around me/ I do not want to make it cohere" (Forrest-Thomson 2008, p. 162) but the poem then rejects its own desires and commands, taking, through its simultaneously violent and nostalgic artifice, a shape and meaning that is not reducible to any conclusive comments about Forrest-Thomson's art but which, nevertheless, achieves its memorialization. "Is this a chisel that I see before me. If so I want to hack my name on the bedroom door." Forrest-Thompson does not close the personal gaps through which a self seeps, a self that at what turns about to be its near end still looks uneasily to possible futures and selves. "Nobody. I, myself" the poem begins, providing an answer to a question that it has not asked, and it ends with a kind of hope that her subsequent real death does not cancel: "On the best battle fields/No dead bodies"10.

Here is the poet, only 13 years old writing as Veronica Thomson in her school magazine:

What are we and what do we here?

And are we what we think we are?

Are you, you, and am I me?

The sky the sky, the sea, the sea?

And are those birds, flying in the air?

And is everything, really there?

The questions of this poem are in their own way as sophisticated, as complex as any questions that are ever asked. They may be confined and limited by attention to conventions with which the teaching at St Bride's would have made Veronica Thomson familiar. Yet, already the 13-year-old poet is refusing any punctuation that might separate the two halves of the first line and in the fourth the "the sky" from "the sky". In this way, the poet makes "the sky the sky" express a kind of wonder and possibility as well as asking existential questions about it. Veronica Forrest-Thomson struggles to escape the limiting conventions taught in her Scottish boarding school but without them she could not have formulated the problematic anti-questions and open answers of her late intellectually inflected international verse.

So, where are we with these four women? How helpful has it been to think of their Scottish formations and connections? Helen Adam and Muriel Spark are most fruitfully explored in terms of the sometimes-warring tugs of their Scottish and world experiences. The balladeer with the perjink accent, chanting about the glorious darkness of the junkie, and the internationalist whose Morningside accent clings with lingering tenacity to the darkness with which it flirts: As Spark puts it in her Ballad of the Fanfarlo, "For there's no scope for a talented type/In the loss of memory." The first and last of these poets have trickier elements in their partly Scottish formation. Mirrlees was physically even more restless than Spark but without Spark's ability to appropriate all the places she inhabited. Yet, like Spark, she refused a loss of memory, writing late in her life about her mother's pedigree and in "Listening to the Past" concluding with that kaleidoscopic image of harmony achieved by the collation of disparate elements. Veronica Forrest-Thomson might have been happier had she clung to the Scottish ties she explored with Edwin Morgan, but then neither the thrills nor the miseries gifted to her

10 These last two lines are taken by Peter Porter, who admired Forrest-Thomson's work, for the title of one of his poems (Porter 2015). 
and imposed upon her in Cambridge, Leicester, Liverpool, the United States, and Birmingham would have been available for her. Scotland gave Forrest-Thomson the nursery rhyme, the ballad: It was all that other experience that made her poems kaleidoscopic. She was, as it were, poised, as were all four poets that I have discussed, between Scotland and Modernism, except that the kaleidoscope, that "toy" that lends itself so easily to Modernist aesthetics, was itself, as I have pointed out, a Scottish invention.

Funding: This research received no external funding.

Conflicts of Interest: The author declares no conflict of interest.

\section{References}

Adam, Helen. 1923. The Elfin Pedlar E Tales Told by Pixy Pool. With a Foreword by Rev. John A Hutten, drawings by the author. London: Hodder \& Stoughton.

Adam, Helen. 1974. Selected Poems and Ballads. New York: Helikon Press.

Adam, Helen. 1977. San Francisco's Burning. PennSound. Available online: http://writing.upenn.edu/pennsound/ x/Adam.php (accessed on 6 December 2019).

Adam, Helen. 1979. Ghosts and Grinning Shadows. With collage illustrations by the author. Brooklyn: Hanging Loose Press.

Baudelaire, Charles. 1847. La Fanfarlo. In Bulletin de la Société des Gens de Lettres. janvier. Paris: Gallica.

Beard, Mary. 2000. The Invention of Jane Harrison. Cambridge: Harvard University Press.

Bernstein, Charles. 1987. Artifice of Absorption: An Essay. Philadelphia: Singing Horse Press.

Briggs, Julia. 2007. Hope Mirrlees and continental modernism. In Gender in Modernism. Edited by Bonnie Kime Scott. Urbana: University of Illinois Press, pp. 261-69.

Caws, Mary Ann. 2018. Review of The Collages of Helen Adam (Cuneiform Press: 2017) for Brooklyn Rail. Available online: https://brooklynrail.org/2018/04/art_books/The-Collages-of-Helen-Adam-ed-AlisonFraser-Further-Other-Book-WorksCunieform-Press-2017 (accessed on 6 December 2019).

Culler, Jonathan. 1981. The Pursuit of Signs: Semiotics, Literature, Deconstruction. London: Routledge.

Dunn, Douglas, ed. 2006. Twentieth-Century Scottish Poetry. London: Faber \& Faber.

Eliot, Thomas Stearns. 2017. The Letters of T. S. Eliot. Edited by Valerie Eliot and John Haffenden. London: Faber \& Faber, vol. 7.

Farmer, Gareth. 2017. Veronica Forrest-Thomson: Poet on the Periphery. Cham: Palgrave Macmillan.

Forrest-Thomson, Veronica. 2008. Collected Poems. Edited by Anthony Barnett. Exeter: Shearsman Books in association with Allardyce Books.

Forrest-Thomson, Veronica. 2016. Poetic Artifice 1978. Edited by Gareth Farmer. Bristol: Shearsman Books.

Gregson, Ian. 1996. Contemporary Poetry and Postmodernism. London: Macmillan.

Isherwood, Christopher. 1997. Diaries, vol. 1, 1939-1960. Edited by Katherine Bucknell. London: Vintage.

Kenny, Maurice. 2018. Angry Rain: A Brief Memoir. Edited by Derek C. Maus. Albany: Excelsior Editions.

Malayan Volunteers Group. 2006. Apa Khabar. Available online: https://www.malayanvolunteersgroup.org.uk/ uploads/1/0/7/3/107387685/mvg_newsletter_edition_1.pdf (accessed on 6 December 2019).

Mirrlees, Hope. 1920. Paris: A Poem. London: Hogarth Press. First published 1919.

Mirrlees, Hope. 1924. The Counterplot. London: Knopf.

Mirrlees, Hope. 1926. Lud-in-the-Mist. London: Collins.

Mirrlees, Hope. 2011. Collected Poems. Edited by Sandeep Parmar. Manchester: Fyfield, Carcanet.

Morgan, Edwin. 1990. Collected Poems. Manchester: Carcanet.

Morgan, Edwin. 1999. Scotland and the World. PN Review 26: 17-23.

Morgan, Edwin. 2015. The Midnight Letterbox: Selected Correspondence, 1950-2010. Edited by James McGonigal and John Coyle. Manchester: Carcanet.

Parmar, Sandeep. 2011. Introduction to Hope Mirrlees, Collected Poems. Manchester: Fyfield, Carcanet.

Porter, Peter. 2015. Chorale at the Crossing. London: Macmillan.

Prevallet, Kristin. 2007. A Helen Adam Reader. Orono: National Poetry Foundation.

Prevallet, Kristin. N.D. Helen Adam's Sweet Company. Available online: http://www.heelstone.com/meridian/ adam4.html (accessed on 6 December 2019). 
Prynne, Jeremy Halvard. 1976. Veronica Forrest-Thomson: A Personal Memoir. Veronica Forrest-Thomson, On the Periphery. Cambridge: Street Editions. Available online: http://jacketmagazine.com/20/pryn-vft.html (accessed on 6 December 2019).

Scottish Poetry Library Website. Helen Adam. N.D. Available online: https://www.scottishpoetrylibrary.org.uk/ poet/helen-adam/ (accessed on 6 December 2019).

Spark, Muriel. 1993. Curriculum Vitae. Harmondsworth: Penguin Books. First published 1992.

Spark, Muriel. 2004. All the Poems. Edited by Barbara Epler. New York: New Directions.

Spark, Muriel. 2014. What Images Return (1962). In The Golden Fleece: Essays. Edited by Penelope Jardine. Manchester: Carcanet.

Spark, Muriel. 2015. Complete Poems. Afterword Michael Schmidt. Manchester: Carcanet.

Stannard, Martin. 2004. Muriel Spark, Baudelaire, and the Quest for Religious Faith. Review of English Studies 55: 91-105. [CrossRef]

Thomson, Veronica. 1960-1961. The Bridesian. Helensburgh: St Bride's School, pp. 49-52.

Woolf, Virginia. 1976. Letters. Edited by Nigel Nicholson and Joanne Trautmann. London: Hogarth Press, 1912-1922. vol. 2.

(C) 2019 by the author. Licensee MDPI, Basel, Switzerland. This article is an open access article distributed under the terms and conditions of the Creative Commons Attribution (CC BY) license (http://creativecommons.org/licenses/by/4.0/). 